\title{
Zapach i dźwięk \\ jako sensoryczne narzędzia marketingu w restauracji
}

\begin{abstract}
Paulina Koziara*
Większość procesów dotyczacych zakupów zachodzi poza świadomościa konsumenta. Wybory, jakich dokonuje, podyktowane sa potrzebami i indywidualnymi preferencjami. Nie mniejszy wplyw na podejmowanie konkretnych decyzji maja działania marketingowe. Mnogość komunikatów docierająca do konsumenta jest tak duża, że marketing oparty tylko na obrazach przestał być wystarczający. Marki korzystające tylko $z$ wizualnych narzędzi sa stabiej rozpoznawalne pośród swoich konkurentów. Dlatego też, obecnie kreowane marki sięgaja po dodatkowe narzędzia marketingowe mające działać kompleksowo na odbiorcę. W przypadku restauracji to zmyst smaku powinien być głównym zmystem świadczacym o marce. Jednak jak pokazuja wszystkie badania przeprowadzone $w$ obszarze marketingu sensorycznego, dopiero wsparcie zapachowe i dźwiękowe spowoduje, że zostanie ona odebrana we właściwy sposób i zapamiętana.
\end{abstract}

Słowa kluczowe: marketing sensoryczny, aromamarketing, audiomarketing, zmysły.

Nadesłany: 17.07.2014 | Zaakceptowany do druku: 05.09.2014

\section{Scent and sound as a sensory tools of restaurant marketing}

Most of the consumer decisions are processed out of the consumer consciousness. Choices are the results of needs and individual preferences. The power of marketing takes very strong as well. Because of multiplicity of communication, marketing based on visual tools is not enough to make a brand visible among its competitors. That is why created brands use more marketing tools to influence more complex on the consumers. On the restaurant market the taste is the main sense but only supported by scent and sound can be perceived and remembered in appropriate way.

Keywords: aromamarketing, audiomarketing, ambient.

Submitted: 17.07.2014 | Accepted: 05.09.2014

JEL: M39

\footnotetext{
Mgr Paulina Koziara - Uniwersytet Warszawski, Wydział Zarządzania.

Adres do korespondencji: Uniwersytet Warszawski, Wydział Zarządzania, ul. Szturmowa 1/3, 02-678 Warszawa; e-mail: koziarap@gmail.com.
} 


\section{Wstęp}

Sposób konsumpcji zmienia się nieustannie. Konsumenci przestali szukać w kupowanych produktach funkcjonalności i możliwości zaspokajania swoich podstawowych potrzeb. Gdyby rozpatrywane były wyłącznie faktyczne funkcje produktów, na rynku nie powstawałaby tak wysoka konkurencja. W sytuacji pełnej racjonalności konsumenta jedynym czynnikiem konkurencyjności byłaby cena. Obecny konsument poszukuje rozrywki poprzez zakup, pobudzenie emocjonalne i zmysłowe, przez co tradycyjny marketing staje się zbyt racjonalny (Blondeau, Tran, 2009). W związku z tym konsumpcja przestaje być aktem zaspokajania potrzeby, a staje się symbolem tożsamości konsumenta (konsumpcja jako integracja), jego pozycji w hierarchii społecznej (konsumpcja jako narzędzie klasyfikacji), doświadczeniem i zabawą. Wbrew głoszonej niegdyś teorii racjonalności przestaje być procesem przemyślanym, w którym nabywca bierze pod uwagę stosunek jakości do ceny. Powszechne jest zjawisko konsumpcji impulsywnej, czyli nieplanowanych zakupów niepotrzebnych rzeczy, a także konsumpcja na pokaz, podwyższająca status konsumenta (Dziewanowska i Kacprzak, 2013).

Aby dostarczyć konsumentowi jak najwięcej bodźców pobudzających go do działania, naukowcy zaproponowali ideę marketingu sensorycznego. Marketing sensoryczny to długofalowa strategia marketingowa oparta na oddziaływaniu na wszystkie pięć zmysłów: węch, słuch, smak, dotyk i wzrok. W odróżnieniu od tradycyjnego marketingu, stosującego głównie bodźce wzrokowe, marketing sensoryczny nie jest nastawiony na działanie krótkookresowej sprzedaży, ale „wyrażanie tożsamości i wartości firmy" (Hulten, Broweus i Djik, 2009, s. 23). Ta zintegrowana koncepcja zmysłowa ma stać się odpowiedzią na potrzebę doświadczania przez konsumentów. Równocześnie wpływa na zapamiętywanie, akceptację i powrót do danej marki.

Celem marketingu sensorycznego jest emocjonalne zaangażowanie odbiorcy bodźców, optymalne dopasowanie rzeczywistości do oczekiwań konsumentów oraz tworzenie dodatkowych linii danej marki i utworzenie niepowtarzalnej marki (Lindstorm, 2005). Doświadczenia wielu marek pokazują, że strategia oparta na marketingu sensorycznym skutkuje wyższym zaangażowaniem konsumentów, wyższą sprzedażą i lepszym odbiorem produktów. Najczęściej przywoływanym przykładem marki korzystającej z marketingu sensorycznego są linie lotnicze Singapore Airlines, posiadające własny zapach, ścieżkę dźwiękową, a także konkretny sposób zachowania i wygląd personelu.

Koncepcję, która przedstawia reakcje człowieka na bodźce sensoryczne zaproponował Robert Woodworth w 1918 roku w Dynamic Psychology (Woodworth, 1918). Teoria o nazwie Stimulus-Organism-Response (S-O-R) (Stymulacja - Organizm - Odpowiedź) mówi o tym, że człowiek, a dokładnie jego ciało, znajduje się pomiędzy bodźcami a reakcjami na nie.

Sposób zachowania człowieka zależy od tego, w jakim aktualnie stanie znajduje się jego ciało. Teoria ta obecnie często cytowana jest w marketingu sensorycznym. W końcu wszystkie bodźce w nim stosowane służą konkretnemu, pożądanemu zachowaniu konsumenta. Stymulatorami do działania, jak podjęcie decyzji czy zakup, moga być czynniki zewnętrzne i wewnętrzne. Zewnętrzne można również nazwać środowiskowymi i należa do nich między innymi bodźce audiowizualne, zapachowe i wpływ społeczeństwa. Wewnętrzne to motywacja konsumenta, jego zaangażowanie, płeć, wiek a także innowacyjność (Dziewanowska i Kacprzak, 2013). Wszystkie te bodźce $\mathrm{w}$ procesie poznawczym są przyswajane i analizowane w oparciu o dotychczasowe doświadczenia, wiedze i schematy. Opierają się na wolnym skojarzeniu, wyobraźni, emocjach i uczuciach. To, co rozgrywa się w ciele przyswajającym bodźce ma dwie płaszczyzny:

- postaw i preferencji,

- uczuć i emocji.

Skutkiem stymulacji jest odpowiedź w postaci zachowania konsumenckiego. Może to być podjęcie decyzji o konkretnym wyborze, zakup, konsumpcja, podjęcie jakiejś aktywności lub doświadczenie (Jacoby, 2002). Model ten zostanie przedstawiony na przykładzie stymulacji zapachem i dźwiękiem, które wywołują określone działanie.

Celem niniejszego artykułu jest przedstawienie możliwości zastosowania bodźców słuchowych i zapachowych przy budowaniu holistycznego wizerunku marki. 
Wybranym na potrzeby artykułu produktem są usługi restauracyjne. Jest to produkt złożony, w którego skład wchodzą serwowane posiłki, otoczenie konsumenta, czyli wygląd i lokalizacja restauracji, jakość obsługi i elementy dopełniające markę, jak muzyka, oświetlenie i zapach. Potrzebą pierwotną zaspokajaną $\mathrm{w}$ restauracji jest głód, jednak jak wspomniano, dzisiejszy konsument poszukuje również niepowtarzalnego doświadczenia. Autorka prezentuje teorie dotyczące wpływu zapachu na pamięć, a także wpływu muzyki na postrzeganie miejsca usługowego, proponując implementacje dodatkowych narzędzi marketingowych $\mathrm{w}$ restauracjach.

\section{Rola zmysłu węchu w restauracji}

Aromamarketing to część marketingu wykorzystująca zmysł węchu, najbardziej niedocenianego spośród zmysłów. Z przyczyn naturalnych najczęściej pobudzanym był i jest zmysł wzroku, który dostarcza najwięcej informacji o otaczającym człowieka świecie. Resztę czerpie on świadomie z komunikatów dźwiękowych. Niedostrzeganie istotności węchu można choćby zauważyć w sferze językowej. W języku polskim osoba niewidząca jest ślepa, niesłysząca - głucha, natomiast nieczująca zapachu nie jest w żaden sposób określana. Wskazuje to na podejście do węchu jako mało istotnego zmysłu. Większość obecnych działań marketingowych nakierowana jest na emisje bodźców wzrokowych i słuchowych, dlatego, aby wyróżnić markę, należy w końcu zwrócić się ku pobudzaniu węchu konsumenta. Jest to zmysł szczególny, który kiedyś odgrywał istotną rolę w walce o przetrwanie. Dzisiejsza wiedza pokazuje, że odgrywa również ogromną rolę dla psychiki i fizyczności człowieka. Ponadto nie można nim manipulować, sterować ani też świadomie pominąć. Przynosi przyjemność (np. w zapachu kwiatów, kosmetyków), ale też ostrzega przed niebezpieczeństwem (np. w postaci zepsutego pożywienia). Dodatkowo zapachy są nieodłącznym elementem pamięci emocjonalnej. $75 \%$ przeżyć emocjonalnych związana jest ściśle z zapachem. Utrata tego zmysłu gwałtownie wpływa na samopoczucie i może prowadzić do stanów depresyjnych (Douek, 1988).

Receptory węchowe wchodzą w skład układu limbicznego, który jest jedną z naj- bardziej prymitywnych części ludzkiego mózgu. Ten z kolei odpowiada za emocje i zachowania opiekuńcze. Ta część mózgu kontroluje również strach i agresję. Dzięki temu układowi człowiek jest w stanie rozpoznawać i interpretować zapachy. Mimo że w mózgu tylko $1 \%$ wszystkich zachodzących w nim procesów dotyczy węchu, to przechowuje bodźce przez bardzo długi czas. Dzięki temu człowiek pamięta zapachy z dzieciństwa i jest w stanie łączyć je z określonymi produktami czy wydarzeniami (Pradeep, 2011). W kontekście marek i marketingu to doskonałe narzędzie do budowania wspomnień i skojarzeń. Do rozpoznania marki potrzebny jest wzrok, ale wygląd logo czy nazwę produktu można zapomnieć, co już jest trudniejsze w przypadku zapachu.

\subsection{Indywidualna percepcja zapachu}

Człowiek jest w stanie rozróżnić 10000 różnych zapachów. W tej grupie znajduja się zapachy oddziałujące na odbiorcę pozytywnie lub negatywnie. Sposób postrzegania zapachu zależy o wielu zmiennych, jednak są zapachy naturalnie przyjemne dla większości ludzi, jak zapachy róży czy wanilii. Do zapachów generalnie uznawanych za nieprzyjemne można zaliczyć zapach zepsutego jajka czy skunksa. Zapachy znane sa przy tym postrzegane jako przyjemniejsze, a czasem przyjemne jako znane, dlatego przy tworzeniu zapachu w strategii marketingowej nie powinno się używać różnych zapachów. Raz przyjęta linia zapachowa czy strategia stosowana konsekwentnie jest lepiej kojarzona i zapamiętywana przez konsumentów.

Mniej oczywistym jest wpływ intensywności zapachu na odbiorcę. Jej próg akceptowalności jest kwestią indywidualną, intensywny zapach dla jednych konsumentów będzie przyjemny, przez innych określany jako „duszacy”. Kobiety preferują delikatniejsze zapachy niż mężczyźni, dzieci wymagają mniej intensywnych doznań niż osoby starsze, u których zmysł ten znacznie się osłabia. Ze względu na duże indywidualne różnice w postrzeganiu zapachu, nie powinno oddziaływać się na konsumentów z tą samą intensywnością (Krishna i Schwarz, 2013).

W marketingu sensorycznym należy szukać takiego punktu nasycenia, który będzie już wyczuwalny dla konsumentów, ale jeszcze nie na tyle mocny by być odpy- 
chającym. Nawet zapach zaliczany do zapachów pozytywnych może przez zbyt wysoką intensywność zostać odebrany negatywnie. Przetwarzanie zapachów w mózgu nie podlega analizie i ma charakter czysto hedonistyczny. Konsument w przestrzeni usługowej nie zastanawia się „co pachnie”, a raczej ocenia go pod kątem ,podoba mi się/nie podoba" (Herz, 2010). W związku z tym każda cecha zapachu powinna zostać dopasowana do marki i odbiorcy.

\subsection{Ambient scent $w$ marketingu}

W marketingu zapach zaczął być używany do promocji i pozycjonowania marki nie tylko produktów, których natywną cechą jest zapach. Zapach rozumiany jako część marketingu sensorycznego „nie jest częścia przedmiotu, ale istnieje $\mathrm{w}$ otoczeniu". Obecnie jest on nieodłączny w przestrzeniach usługowych - hotelach, $\mathrm{u}$ fryzjera, restauracjach. Zapach w nich stosowany to tzw. ambient scent, który nie jest zapachem utworzonym przez produkt. Jest kontrolowany i utworzony na potrzeby marki, tworzy atmosferę w miejscu sprzedaży. Ma wpływ na zachowanie, satysfakcję, emocje i pamięć konsumenta. Dzięki niemu, marki są lepiej rozpoznawalne i zapamiettywane (Yun i Yazdanifard, 2013). W odróżnieniu od muzyki, którą słyszą konsumenci, zapach pozostanie prawie niezauważony, do tego stopnia, że nie zdają sobie sprawy, że został on wprowadzony do ich otoczenia (Roxana i Ioan, 2013). Wg Lindstorma zapachy ambientowe to często zapachy, które w rzeczywistości nie istnieją, jak choćby zapach nowego samochodu. Zostały one jednak stworzone ze względu na odbiór produktu przez konsumenta, dla którego „zapach nowości” podnosi wartości na przykład wspomnianego samochodu. Marki stosujące aromat nowości, utrzymujący się przez sześć miesięcy, przyzwyczajają do niego konsumentów. Przez to tworzą nową jakość nieistniejących zapachów ambientowych.

\subsection{Zapach $w$ restauracji}

Zmysł węchu jest kojarzony przede wszystkim $z$ jedzeniem, więc stanowi on znaczące narzędzie na rynku restauracyjnym. Po przekroczeniu progu restauracji jest pierwszą informacją na temat marki, standardu i podawanych potraw. Jako jeden $\mathrm{z}$ istotniejszych elementów $\mathrm{w}$ restauracji powinien być stosowany ze szczególną dbałością. Czas przebywania w restauracji jest dość krótki. Rozpoczyna się już przed wejściem, kiedy oceniany jest budynek, lokalizacja i standard miejsca. Dlatego też doznania w niej serwowane powinny dostarczać wyjątkowych emocji i wrażeń zmysłowych, które w tym krótkim czasie zostaną spostrzeżone, powiązane z marką i odpowiednio zapamiętane. W tym celu stosuje się coraz częściej aromamarketing.

W zależności od zastosowanego zapachu aromamarketing ma na celu:

- stworzenie atmosfery (przestrzeń usługowa wspierana przez zapach może uzyskać świeżość, charakter, narodowość);

- wprawienie konsumenta w określony stan (pobudzenia lub relaksu);

- wspomaganie zapamiętywania (logo, miejsce i marka są lepiej zapamiętywane, jeśli bodźce wizualny wspomagany jest zapachem);

- sterowanie zachowaniem (wybór, zakup, dłuższe przebywanie w miejscu obsługi, powracanie) (Österberg, 2008).

Zmysł węchu jest nazywany ,zmysłem bliskim" co jednak nie oznacza, że kontakt z produktem musi być bezpośredni. Jego bliskość polega na dotarciu cząsteczek do ludzkiego nosa. Węch rozpoznaje to, co niewidoczne i wtedy może prowadzić do wzrokowego poszukiwania jego źródła, dlatego nie należy ograniczać się do zapachu rozpylanego wyłącznie $\mathrm{w}$ restauracji. Równie ważne jest otoczenie czy zapach produktów (Kostera, 2002).

Niechlubnym przykładem niewłaściwego zapachu jest zapach w restauracjach McDonald's, którym dla wielu klientów jest zapach starego oleju (Pradeep, 2011). Głównym celem tego miejsca jest szybka obsługa i opuszczenie przez klienta przestrzeni dla nowych konsumentów. Zapach smażonego oleju nie sprzyja długiemu przebywaniu w takim miejscu. W przypadku McDonald'sa prócz braku zapachu ambientowego jest to efekt braku oddzielonej przestrzeni usługowej od miejsca przygotowywania posiłków. Luksusowe restauracje nie ukrywają kuchni przed wzrokiem konsumentów, dbając o transparentność przygotowywanych posiłków. Jednak w takim wypadku konieczne jest zadbanie o pochłaniacze zapachów, które umożliwią konsumentom doświadczanie zapachu tylko zamówionych przez nich potraw. 


\subsubsection{Spójność zapachowa}

Zapach w miejscu spożywania posiłków powinien być przede wszystkim zapachem naturalnym i spójnym z serwowanymi positkami (strategia firmy Starbucks zawiera określony zapach jako zapach świeżej kawy). Zgodność zapachu z produktem wpływa na pozytywny odbiór samych produktów, ale też na samych klientów, którzy stają się bardziej elastyczni, skłonni do eksperymentowania i bardziej lojalni (Hulten, Broweus i Djik, 2011). Jeśli w danym miejscu nie jest serwowany jeden rodzaj produktów, np. kawa, mięso, warzywa, można zastanowić się nad nadaniem im wspólnego mianownika. Racjonalnym wyjściem z takiej sytuacji jest odnalezienie zapachu, który może kojarzyć się konsumentowi z całą restauracją (np. restauracje z greckimi potrawami). To on pozwoli później odróżnić markę od konkurencji, dzięki czemu stanowi podpis zapachowy marki (Davies, Koojiman i Ward, 2003). Zgodność dotyczy również kontekstu, w jakim znajduje się konsument. Dla restauracji może to oznaczać użycie zapachu cynamonu czy grzanego wina zimą lub świeżej cytryny z miętą latem.

\subsubsection{Wplyw na konsumenta}

Zapach działa dwustronnie na: odbiór restauracji, ale też nastawienie konsumenta. Zmienne te są zależne, dlatego odpowiednie nastrojenie konsumenta wpływa na odbiór restauracji i odwrotnie. Przy doborze zapachu należy zaznaczyć, że szczególnie zapachy jednoskładnikowe mają wyraźny wpływ na humor i samopoczucie odbiorców. W stan relaksu wprawia ludzi lawenda, bazylia, cynamon i cytrusy. Pobudzają ich natomiast: mięta, tymianek i rozmaryn. W restauracjach o wystroju romantycznym jako odpowiednie zostały sprawdzone zapachy imbiru, kardamonu, lukrecji i czekolady (Chebat i Michon, 2003). Zastosowanie któregoś z powyższych wpływa na czas spędzony w restauracji, jak i ilość wydanych pieniędzy. Badania Gueguen i Petr pokazały, że klienci spędzali więcej czasu i pieniędzy, gdy byli poddawani działaniu zapachu lawendy w nowej restauracji (Gueguen i Petr, 2006). W sklepach najczęściej stosowanym jest zapach świeżo upieczonego chleba, który ma kojarzyć się z domem, ale równie dobrze na wzrost sprzedaży działa zapach pomarań- czy, a także każdy inny jednoskładnikowy, przyjemny zapach. Dzieje się tak dlatego, że zmysł zapachu trafia prosto do części mózgu odpowiedzialnej za emocje, bez poddawania go jakiejkolwiek analizie. Zapachy te mają większy wpływ na konsumenta i jego skłonność do wydatków. Bardziej skomplikowane zapachy, przygotowane mieszanki, nie maja już tak silnego działania (Spangenberg, 2013).

Sam proces zaspokajania potrzeby podstawowej (głodu) poddawany jest podobnym mechanizmom w sklepach spożywczych, gdzie szeroko stosowane są zapachy jednoskładnikowe. Przykładem kompleksowej strategii aromatycznej jest supermarket NetCost w Nowym Jorku, w którym zamontowano 5 maszyn wydzielający między innymi zapach grejpfruta, czekolady czy rozmarynu w zależności od działu. Dzięki temu konsumenci czują zmianę każdym zmysłem, co jest spójne $\mathrm{z}$ tym, co widzą. W restauracji może znaleźć to zastosowanie przy zmianie menu, wtedy też powinien zmienić się zapach całego otoczenia.

Słodkie zapachy mają pozytywny wpływ na zachowania społeczne, dlatego w restauracjach znajdują zastosowanie przy kasach lub miejscach, gdzie konsument najczęściej ma do czynienia z personelem. Może to być pobliże kas, baru czy wejście do restauracji. Badania Barona pokazały, że ludzie sa bardziej życzliwi i częściej pomagają sobie w otoczeniu właśnie tych zapachów (Baron, 1996).

Przy wprowadzaniu nowej marki na rynek lub otwieraniu nowej restauracji należy wspomnieć o badaniach Morrin i Ratneshar. Odkryli, że zapach geranium wpływa na lepsze zapamiętywanie. Początek działalności, zmiana logo czy też nazwy wspierane przez ten zapach osiaggają lepsze efekty (Morrin i Ratneshar, 2000).

Zastosowanie zapachu $\mathrm{w}$ restauracji dotyczy zazwyczaj całego pomieszczenia, co uniemożliwia bardziej spersonalizowane bodźce zapachowe. Taką możliwość dają toalety, gdzie zapachy kobiece i męskie mają większe znaczenie. To miejsce również świadczy o marce i zapada w pamięć. Niepożądanym w kontekście otoczenia restauracyjnego bedzie wspomnienie środków chemicznych. Badania pokazują, że nie wszystkie zapachy są w sposób oczywisty kobiece lub męskie. W kontekście zapachów jednoskładnikowych kobiety preferują np. zapach waniliowy, mężczyźni - róży marokańskiej (Zaltman, 2003). 
Podsumowując, należy wskazać, że w otoczeniu restauracji, ale też w budowaniu każdej marki należy wziąć pod uwagę trójwymiarowość zapachu. Po pierwsze, musi być on dopasowany do serwowanych produktów, stylu restauracji lub klimatu w niej utrzymanego. Po drugie, musi istnieć w przestrzeni usługowej. Jego obecność zapewnia dłuższe przebywanie w restauracji, zakup większej ilości produktów, częstsze powracanie do jednego miejsca. Po trzecie, aby wywierać odpowiedni skutek, musi być on przyjemny, z zachowaniem progu tolerancji intensywności (Roxanaa i Ioan, 2013). Lepiej jest więc zrezygnować z wspólnej powierzchni kuchennej i usługowej, by uniknąć zapachu przypalonego jedzenia czy starego oleju.

\section{Muzyka jako element budujący atmosferę restauracji}

Dźwięk jest kolejnym bodźcem budującym atmosferę danego miejsca. To dzięki dźwiękom człowiek poznaje świat. Od pierwszych dni odróżnia głos matki, który kojarzy mu się z bezpieczeństwem, uczy się znaczenia dźwięków. Człowiek poznaje różne dźwięki, częstotliwość, natężenie i łączy je ze znanymi mu zjawiskami, na przykład wysoki, głośny dźwięk z niebezpieczeństwem. Z uwagi na ilość dźwięków jakie go otaczają, część nie zostanie bezpośrednio rozpoznana i świadomie zarejestrowana. Dźwięk nie jest namacalny, podobnie jak zapach, dlatego interpretowany jest różnie przez jednostki. W analizie wpływu dźwięku na zachowania należy brać pod uwagę różnice między słyszeniem i słuchaniem. Te dwie pozornie podobne czynności mają różny skutek w oddziaływaniu na odbiorcę.

Słyszenie rozumiane jako akt pasywny, działający często na podświadomość, mający wpływ na poruszanie się i tempo zakupów. Słuchanie natomiast jest świadomą czynnością słyszenia. Wymaga większej uwagi, ale podlega świadomemu zapamiętaniu dźwięków (Lindstrom, 2005). $\mathrm{W}$ tej części artykułu autorka skupi się na oddziaływaniu muzyki na klienta restauracji i jego zachowania.

\subsection{Zastosowanie muzyki}

Muzyka w przestrzeni usługowej jest świadomie wykorzystywana niemal we wszystkich branżach od wielu lat. Miała i ma na celu działanie zarówno na klientów, jak i pracowników. Z perspektywy psychologii muzyka ma wpływ na wszystko - humor, podejście do produktu i ludzi. Nie bez przyczyny mówi się, że „muzyka łagodzi obyczaje". Audiomarketing wykorzystuje podświadomy wpływ na zachowanie konsumenta i ma zastosowanie przy okazji wszystkich narzędzi stosowanych w tradycyjnym marketingu. Wpływa na postrzeganie ceny, miejsca, ludzi i produktów. Jest bardzo ważnym elementem reklam telewizyjnych, podstawowym - radiowych, pojawia się na stronach internetowych, podkreślając tożsamość firmy, bannerach, pre-rollach, jest dodatkiem do citylightów i tworzy tło w reklamach ambientowych, jednak największą wartość dla klienta przedstawia w miejscu zakupu lub, jeśli to możliwe, jako część produktu.

Muzak, bo tak nazywana jest muzyka funkcjonalna, czyli odpowiednik zapachu ambientowego, to wypełniacz i zagłuszacz dźwięków niepożądanych. W życiu codziennym spotykana jest $\mathrm{w}$ pracy, miejscach publicznych i przestrzeniach konsumpcyjnych. Ma za zadanie regulować procesy i zachowania zachodzące w tych miejscach. Przez wszechobecność, ale przy tym niewidzialność, muzak jest jednym z największych obszarów produkcji muzycznej (Jones i Schumacher, 1992). W restauracji tłumi odgłosy dochodzące z kuchni, przesuwanych krzeseł, nowych gości czy rozmów prowadzonych przy stolikach. W obecnej teorii marketingu powyższe funkcje nie są jednak jej głównymi celami.

\subsection{Wielowymiarowość muzyki}

Przy analizowaniu muzyki jako narzędzia marketingowego należy brać pod uwage jej wielowymiarowość. Może mieć ona różne tempo, głośność, styl, udział instrumentów i wokal. Dzięki temu wpływa na takie zmienne, jak zachowanie konsumenta, szybkość wykonywania przez niego czynności wyboru i zakupu, dokonywanie wyboru, ocena produktu i miejsca, a także oceny czasu spędzonego $\mathrm{w}$ danym miejscu (Gueguen, Jacob, Lourel i Guellec, 2007). Muzyka jako bodziec została bardzo dokładnie przebadana w każdym jej wymiarze, dzięki czemu możliwe jest zbudowanie strategii, która będzie odpowiadała potrzebom marki. Odpowiedni dobór muzyki jest uzależniony, jak w przypadku każdego ze zmysłów, od sprzedawanego produktu. 
Powinna być dostosowana do grupy docelowej i charakteru restauracji. Jeśli chodzi o grupę docelową, zazwyczaj nie będzie to podział ze względu na płeć, a raczej status społeczny, wiek, zamożność klienta i jego preferencje. Poszczególne dopasowania będą zależeć od wszystkich wspomnianych składowych: głośności, tempa, ilości bodźców - muzyka instrumentalna lub z wokalem, stylu i dopasowania.

\subsubsection{Indywidualny próg głośności}

Pierwsza składowa, czyli głośność muzyki jest zmienną indywidualną, a jej próg zmienia się w zależności od wieku, płci i upodobań odbiorcy. To, co dla młodego konsumenta będzie jeszcze normą, dla starszej osoby może już przekraczać jej próg komfortu przebywania w danym miejscu. Co do zasady zbyt głośna muzyka powoduje, że konsumenci spędzają w miejscu zakupu mniej czasu, niż gdyby była ona tylko tłem. W badaniu przeprowadzonym w 1100 supermarketach głośność nie wpływała istotnie na wielkość sprzedaży ani na satysfakcję klienta (Smith i Curnow, 1996). W przypadku restauracji czas $w$ niej spędzony jest kluczową i powiązaną $\mathrm{z}$ wielkością wydatków zmienną. Jeśli muzyka jest zbyt głośna, przebywanie w restauracji traci swój podstawowy cel, jakim jest przebywanie $\mathrm{z}$ innymi ludźmi i rozmowa $\mathrm{z}$ nimi.

\subsubsection{Tempo muzyki}

Dla ludzkiej psychiki ma znaczenie $w$ jakim przebywa środowisku $\mathrm{i}$ jakie oddziałują na niego bodźce. W muzyce, to jej tempo ma znaczny wpływ na pobudzenie lub wygaszenie nastroju odbiorcy. Jako zmienna została dość dokładnie zbadana ze względu na jej oczywiste różnice, które są obiektywne dla wszystkich odbiorców. O ile głośność, znajomość utworów i ich „lubienie" jest sprawą indywidualną, o tyle w przypadku tempa nie ma takich wątpliwości. Jako tempo muzyki należy rozumieć szybkość z jaką muzyka się zmienia. Liczone jest zazwyczaj w bitach na minutę. Poniżej wartości 72 bpm to muzyka wolna, a powyżej 94 bpm - szybka (Gueguen i in., 2007). Wolniejszy rytm sprzyja bardziej leniwemu przechadzaniu się klientów po sklepie czy dłuższemu wybieraniu posiłków. Wpływa bezpośrednio bardziej relaksująco na odwiedzających, a to z kolei przekłada się na wzrost sprzedaży (Milliman, 1982). W restauracjach szybkiej obsługi, gdzie istotny jest duży przepływ konsumentów, którzy szybko opuszczają restaurację i zwalniają stoliki, zastosowanie znajduje szybka muzyka. Tempo muzyki powoduje nie tylko, że konsumenci dostosowuja swój sposób poruszania się do jej rytmu, lecz także powoduje, że zmienia się ich percepcja czasu.

\subsubsection{Percepcja czasowa}

Postrzeganie czasu i jego zapamiętywanie zależy od wielu czynników zewnętrznych. Pamięć jest w stanie pomieścić określoną ilość bodźców i na tej podstawie oceniać długość czasu. Podczas wieloletnich badań (Kellaris i Kent, 1992) wykazano, że tempo muzyki ma wpływ na postrzeganie upływu czasu. Percepcja czasu klientów ma duże znaczenie, szczególnie w miejscach usługowych, jak restauracje, gdzie czas regulowany jest przez obsługę. Konsument czeka na stolik, przyjęcie zamówienia, obsługę, dostarczenie posiłków i na koniec - rachunek. Wszystkie te czynności zależą od wielu osób w restauracji, jak kelner, kasjer, kucharz i sam konsument. Nikt nie lubi czekać, dlatego regulowanie podejścia klienta i jego humoru może mieć decydujące znaczenie w kształtowaniu odbioru takiego miejsca. Ogólna zasada mówi o tym, że im więcej bodźców dostarczanych do organizmu, tym więcej informacji do przetworzenia. Z kolei większa ilość informacji oznacza, że postrzegany czas się wydłuża. Muzyka, która dostarcza niewielu bodźców będzie powodowała, że czas wydaje się krótszy niż w przypadku muzyki, która dostarcza ich dużo. Jako muzykę z niewielką ilością bodźców można tu wskazać niezawierającą słów lub taką, która nie zmienia się zbyt często lub też nie jest znana odbiorcy. Zgodnie z powyższym, osoba czekająca na złożenie zamówienia 10 minut $\mathrm{w}$ restauracji, gdzie nie ma muzyki będzie szacowała czas oczekiwania jako krótszy, niż słuchająca popularnej piosenki (Wearden, 2008). W powyższym stwierdzeniu nie zostały jednak wzięte pod uwagę dodatkowe czynniki, które wpłyną później na odbiór takiego miejsca, jak choćby nastawienie, humor i emocje, jakie moga towarzyszyć osobie siedzącej w cichym pomieszczeniu.

Intuicyjnie można powiedzieć, że czas wydaje się krótszy, jeśli muzyka budzi pozytywne emocje, a najczęściej takie emocje budzą utwory już znane słuchaczowi. 
Według badań Kellaris i Kent nie jest to zasada. Słuchając znajomej muzyki, ludzie mają wrażenie, że więcej się dzieje, skupiają się bardziej na słowach piosenki, angażując się w melodię i tekst. Mimo tego, że czas w ich odczuciu płynie wolniej, chętniej wracaja do takich miejsc (Kellaris i Kent, 1992). Ponadto popularna muzyka, którą każdy kojarzy, jak i jazz są bardziej rozpoznawane przez konsumentów. Zapytani o obecność muzyki czéściej byli w stanie słyszeć jej obecność. Wiedzieli, że wystawieni sa na działanie muzyki. W zawiązku z tym była odbierana w sposób świadomy, więc przechodzili od słyszenia do słuchania (Wilson, 2003).

W przypadku restauracji ma to zastosowanie nie tylko w samej przestrzeni usługowej, lecz także przy zamówieniach telefonicznych. Osobom czekającym na połączenie lub złożenie zamówienia wydaje się, że czekają krócej, jeśli słyszą melodię (Gueguen i Jacob, 2002). Inne badania mówią o tym, że to właśnie znajoma melodia powoduje, że odbiorcy są w stanie przywołać przekazywany im komunikat. Badane komunikaty odtwarzane w towarzystwie szybkiej i wolnej muzyki wykazały, że respondenci lepiej zapamiętują slogany, słuchając wolnej, znajomej melodii (Hang i Hwang, 1999). Z kolei Oakes i North (2006) przeprowadzili badania sprawdzające percepcję i pamięć w zależności od tempa muzyki. Trzy klipy zawierały muzykę o szybkim tempie, wolnym lub nie miały wcale muzycznego tła. Wyniki wykazały, że w przypadku reklam najsłabiej zapamiętywane były komunikaty z szybką muzyką, najlepiej - bez żadnego podkładu muzycznego. Sugeruje to, że muzyka, nawet jeśli ma reprezentować markę, musi być umiejscowiona w taki sposób, by nie tworzyła dodatkowego chaosu informacyjnego, a jedynie wspierała istniejące $w$ otoczeniu bodźce. W przypadku sieci restauracji, dynamiczna muzyka może spowodować problemy w zapamiętaniu hasła reklamowego.

Muzyka swoim tempem wpływa zarówno na samych konsumentów, jak i na personel. W restauracjach wolniejsze tempo obsługi wpływało na wszystkie pozostałe czynności. Klienci siedzący w restauracji rzadko kiedy wychodzą, jeśli czas ich obsługi nieznacznie się wydłuży. W odróżnieniu od sklepów, do których chodzą raczej z przymusu, restauracje są miejscami spotkań, gdzie konsu- menci przychodzą się zrelaksować, spotkać z innymi ludźmi i porozmawiać. Stają się przy tym zależni od reprezentantów marki i obsługi restauracji. Wolniejsza obsługa oznacza dłuży czas spędzony w restauracji, a to z kolei więcej zamówionego jedzenia i wypitego napoju, co jest równe wyższej sprzedaży (Milliman, 1982).

\subsubsection{Rodzaj muzyki a regulacja zachowań}

Muzyka ze względu na styl powinna zostać dostosowana do typu klienta, do którego jest skierowana. Młodzi konsumenci zazwyczaj preferują bardziej dynamiczną muzykę niż osoby starsze. Dodatkowo znaczenie ma czy muzyka jest pierwszoplanowa, głośna i stanowiąca główny dźwięk, czy też tworzy tylko tło i atmosferę. Młodsze osoby lepiej reagują na muzykę pierwszoplanową, która stanowi główny temat i wypełnia miejsce usługowe. Bardziej dojrzali konsumenci wolą, żeby głośna muzyka nie rozpraszała ich podczas robienia zakupów, ale tworzyła tło i dodawała atmosfery (Yalch i Spangenberg, 1993).

Wilson (2003) przeprowadził badania dotyczące wpływu rodzaju muzyki na odbiór restauracji. Muzyka klasyczna powodowała, że konsumenci postrzegali restauracje jako bardziej wykwintną i droższą. Popularna, słuchana na co dzień, wyzwalała pozytywne skojarzenia i wywoływała najbardziej pozytywne emocje. Brak muzyki powodował, że konsumenci oceniali ją co najwyżej jako przyjemną. Jazz pobudzał i sprawiał, że restauracja postrzegana była jako głośna, ale przez to atmosfera panująca była ożywiona. Wzrost liczby osób w restauracji sprawiał, że muzyka była oceniana jako bardziej agresywna. Przez to, ten rodzaj może nie sprawdzać się dobrze w zatłoczonych miejscach, których konsumenci będą unikać.

Wilson sprawdził również, która muzyka skłania do największych wydatków. Okazuje się, że chęci wydania więcej nie wywoływała muzyka klasyczna, ale jazzowa. Szczególnie zaobserwowano to przy sprzedaży alkoholu, która rosła, kiedy muzyka była młodzieżowa, radosna i zabawna, a spadała w przypadku braku muzyki i muzyki klasycznej. Najmniej ludzie chcą wydawać, gdy bodziec audio nie występuje wcale (Wilson, 2003).

$\mathrm{Z}$ powyższych badań wynika, że przy doborze stylu muzyki należy określić cel jej zastosowania: jaka atmosfera ma być odbierana przez konsumentów, jak mają 
postrzegać lokal i jego ceny czy celem jest by przebywali dłużej w restauracji, czuli się odświeżeni i pobudzeni, czy ukojeni i zrelaksowani. Jeśli głównym produktem podwyższającym zysk jest alkohol, to nie powinni słuchać muzyki klasycznej, chyba że do spożycia mają wyrafinowane potrawy i alkohole, których nie pije się w dużych ilościach.

\subsubsection{Dopasowanie wspierajace postrzeganie}

Przy doborze stylu najważniejsze jest, podobnie jak w przypadku zapachu, dopasowanie muzyki do stylu restauracji. Oznacza to, że muzyka powinna pasować do otoczenia restauracyjnego. Błedy związane $\mathrm{z}$ nieodpowiednim dopasowaniem maja znacznie większe skutki niż całkowity brak muzyki. Ponadto źle dopasowana muzyka rozprasza, a nie pomaga przy dokonywaniu wyborów (Kanner, 1992). W większości badań nad muzyką sprawdzana jest również jej „odpowiedniość”. Tak jak muzyka francuska podnosiła sprzedaż francuskiego wina, a niemiecka - wina niemieckiego, tak również dopasowanie narodowej muzyki do narodowości restauracji będzie wpływać na satysfakcję z danego posiłku (North, Hargeaves i McKendrick, 1999). To dopasowanie odgrywa ogromną rolę we właściwym postrzeganiu restauracji. Badani spędzali więcej czasu i przez to wydawali więcej pieniędzy w tych miejscach, gdzie muzyka była przez nich oceniana jako „odpowiednia”.

\subsubsection{Dźwięki otaczajace markę}

Prócz muzyki w miejscu zakupu, konsumentowi dźwięki towarzyszą o wiele częściej. Są to dźwięki związane bezpośrednio $\mathrm{z}$ używaniem produktów, na przykład dźwięk otwieranego wina, pieczonego kurczaka czy wlewanego do szklanki napoju. Marki multisensoryczne projektuja niektóre dźwięki, dbając w ten sposób o tożsamość swojej marki. Konsumenci czasem świadomie przyznają, że dźwięk dzwonka w telefonie zadecydował o jego zakupie. Przykładami może być tu dźwięk Nokii rozpoznawany przez $41 \%$ konsumentów na całym świecie, otwieranego systemu Windows czy melodia charakterystyczna dla samochodów z lodami Family Frost. Są również bardziej „planowane” dźwięki, jak dżingle pojawiające się w reklamach, przy okazji ekspozycji logo (np. McDonalds) (Lindstrom, 2005). W kontekście restau- racji należy pamiętać, że drobne dźwięki, między innymi otwieranego wina lub piwa w towarzystwie klienta, również tworzą atmosferę tego miejsca. Dźwięk, jaki ma kojarzyć się z restauracją, można umieścić na stronie internetowej, przy wejściu do restauracji lub stosować jako przerywnik między utworami.

\section{Podsumowanie}

Rosnąca konkurencja i oczekiwania klientów wymaga od restauratorów dodatkowego zaangażowania $\mathrm{w}$ przygotowanie swoich miejsc usługowych tak, by dostarczały one dodatkowych bodźców i wrażeń. Cytowane badania pokazują, że stosowanie audio- i armomamarketingu wpływa na pamięć i odbiór restauracji. Strategie klasycznego marketingu powinny zostać wzbogacone o narzędzia oddziałujące w sposób podświadomy na wszystkie zmysły konsumenta. Restauracje są złożonym produktem, gdzie podstawowa potrzeba pożywienia łączy się z zachowaniami społecznymi, w odbiorze których znaczące miejsce zajmuje otoczenie. Węch i słuch jako zmysły odbierające nienamacalne bodźce moga zostać wykorzystane do wzmocnienia tożsamości marki, zapamiętania, pozytywnego odbioru, wzrostu sprzedaży i regulowania zachowań konsumentów. Zarówno zapachy, jak i dźwięki są bodźcami o złożonej naturze. Mogą mieć zmienną intensywność, rodzaj i styl. Oddziałują przy tym różnie na każdego człowieka, na czym polega trudność w jego odpowiednim dobraniu. Najważniejsze okazuje sie dopasowanie ich do stylu restauracji tak, by uniknąć nieprzyjemnego dla odbiorcy dysonansu poznawczego. Jeśli wszystkie elementy są postrzegane jako spójne, wzrasta poziom zaangażowania i lojalności klientów. Bodźce te działają na wszystkie osoby przebywające $\mathrm{w}$ restauracji, dlatego moga mieć pozytywny (lub negatywny) wpływ na klientów, pracowników, ich relacje i zachowania względem siebie. Przyjemne zapachy o odpowiedniej intensywności powodują: lepsze zapamiętywanie, odprężenie, pozytywny odbiór atmosfery i wolniejsze ruchy. Podobnie wolna, dopasowana muzyka, tworząca tło dźwiękowe relaksuje klientów, którzy przebywając dłużej w restauracji, wydają więcej. Ponadto wpływa na postrzeganie czasu i chęć powrotu do danego miejsca. 
Wszystkie narzędzia oddziałujące na zmysły człowieka, zgodnie z teorią Stimulus-Organism-Response znajdą odzwierciedlenie w zachowaniach konsumentów. Ponadto używając wszystkich możliwych kanałów dotarcia do pamięci i umysłu odbiorcy, wzmacnia się świadomość marki.

\section{Bibliografia}

Allan, D. (2007). Sound Retailing: A Review of Experimental Evidence on the Effectsof Music on Shopping Behavior, European Journal of Marketing, 45(1-2), 104-132.

Baron, R.A. (1997). The Sweet Smell of ... Helping: Effects of Pleasant Ambient Fragrance on Prosocial Behavior in Shopping Malls, Personality and Social Psychology Bulletin, 23(5), 498-503, http://dx.doi. org $/ 10.1177 / 0146167297235005$.

Blondeau, M. i Tran, A. (2009). Scent Marketing: What is the impact on stores in Umeå?. Uniwersytet Umea. Pozyskano z: http://urn.kb.se/resolve?urn=urn:nbn:se:umu:diva-23478 (02.07.2014).

Chebat, J.C. i Michon, R. (2003). Impact of ambient odors on mall shoppers' emotions, cognition, and spending A test of competitive causal theories, Journal of Business Research, 56, 529-539.

Davies, B.J., Kooijman, D. i Ward, P. (2003). The Sweet Smell of Success: Olfaction in Retailing, Journal Of Marketing Management, 19(5/6), 611-627.

Dziewianowska, K. i Kacprzak, A. (2013). Marketing doświadczeń. Warszawa: Wydawnictwo Naukowe PWN.

Gaygen, D. (2013). Effects of Ambient Music Exposure on Simulated Buy Decisions, International Journal of Business and Social Science, 4(4), 184-196.

Gueguen, N. i Petrb, C. (2006). Odors and consumer behavior in a restaurant, International Journal of Hospitality Management, 25, 335-339.

Gueguen, N. i Jacob, C. (2002). The influence of music on temporal perceptions in an on-hold waiting situation, Psychology of Music, 30(2), 210-214.

Gueguen, N., Jacob, C., Lourel M. i Guellec, H. (2007). Effect of Background Music on Consumer's Behavior: A Field Experiment in a Open-Air Market, European Journal of Scientific Research, 16(2).

Hahn, M. i Hwang, I. (1999). Effects of tempo and familiarity of background music on message processing in TV advertising: A resource-matching perspective, Psychology \& Marketing, 16(8), 659-675.

Herrmann, A., Zidansek, M., Sprott, D.E. i Spangenberg, E.R. (2013). The Power of Simplicity:
Processing Fluency and the Effects of Olfactory Cues on Retail Sales, Journal of Retailing, 89(1), 30-43.

Hulten, B., Broweus, N. i Djik, M. (2011). Marketing sensoryczny. Warszawa: Polskie Wydawnictwo Ekonomiczne.

Jacoby, J. (2002). Stimulus-Organism-Response Reconsidered: An Evolutionary Step in Modeling (Consumer) Behavior, Journal of consumer psychology, 12(1), 51-57.

Jones, S.C. i Schumacher, T.G. (1992). Muzak: On functional music and power, Critical Studies in Mass Communication, 9(2), 156-169, http://dx.doi. org/10.1080/15295039209366822.

Kanner, B. (1992). Selling with music. New York, 25, 12-14.

Kellaris J.J. i Kent J. (1992). The influence of Music on Consumers' Temporal Perceptions: Does Time Fly When You're Having Fun?, Journal of Consumer Psychology, 1(4), 365-376

Köster, E.P. (2002). The Specific Characteristics of the Sense of Smell. W: Olfaction, taste and cognition. Cambridge: Cambridge University Press.

Krishna, A. i Schwarz, N. (2014). Sensory marketing, embodiment, and grounded cognition: A review and introduction, Journal of consumenr psychology, 24(2), 159-168.

Lindstorm, M. (2005). Brand sense. Nowy Jork: Free Press, Simon\&Schuster.

Milliman, R.E. (1982). Using background music to affect the behavior of supermarket shoppers, Journal of Marketing, 46(2), 86-91.

North, A.C., Hargreaves, D.J. i McKendrick, J. (1999). The influence of in-store music on wine selections, Journal of Applied Psychology, 84(2), 271-276.

North, A.C., Shilcock, A. i Hargreaves, D.J. (2003). The effect of musical style on restaurant customers' spending, Environment and Behavior, 35(5), 712-718.

Oakes, S. (2003). Musical tempo and waiting perceptions, Psychology \& Marketing, 20(8), 685-705.

Oakes, S. i North, A.C. (2006). The impact of background Musical tempo and timbre congruity ad content recall and affective response, Applied Cognitive Psychology, 20(4), 505-520.

Österberg, M., (2009). Exploring the effects of ambient scent on consumers in service scapes, HANKEN- Swedish School of Economic and Business Administration. Pozyskano z: http://www.smellit.cl/assets/pdf/hanken2.pdf (30.06.2014).

Pradeep, A.K. (2011). Mózg na zakupach. Gliwice: Wydawnictwo Helion.

Roxanaa, O. i Ioan, P. (2013). The Effects of Ambient Scent on Consumer Behavior: A Review of 
the Literature, Economic Science Series, 22(1), 136-175.

Smith, P.C. i Curnow, R. (1966). Arousal hypotheses and the effects of music on purchasing behavior, Journal of Applied Psychology, 50(3), 255-256.

Wearden, J.H. (2008). The Perception of Time: Basic Research and Some Potential Links to the Study of Language, Language Learning, 58, 149-171.

Wilson, S. (2003). The effect of music on perceived atmosphere and purchase in a restaurant, Psychology of Music, Society for Education, Music and Psychology Research, 31(1), 93-112.
Woodworth, R.S. (1918). Dynamic psychology. Columbia University Lectures. Londyn: Columbia University Press.

Yalch, R. i Spangenberg, E. (1993). Using store music for retail zoning, Association for Consumer Research, 20, 632-636.

Yun, O.W. i Yazdanifard, R. (2013). Correlation between ambient scent and the brand positioning within consumers unconscious self, Global Journal of commerce \& Management perspective, 2(6), $12-15$.

Zaltman, G. (2003). How Customers Think: Essential Insights into the Mind of the Market, Harvard Business School Press, 2. 